\title{
The Implementation of Decentralization Reform Policy in Tanzania: The Case of Singida Municipality
}

\author{
Dr. Andrew Sulle \\ Department Mzumbe University, Dar es Salaam Campus College Tanzania
}

\begin{abstract}
The aim of this paper was to understand the implementation of decentralization policy in Tanzania. Just like many other countries in Africa and elsewhere, Tanzania has also adopted decentralization policy for various reasons. The main objectives of the paper was to assess and determine the extent to which decentralization policy has been fully implemented in Tanzania and identify factors that inhibit effective implementation of the decentralization policy. The study used a case study design and Singida municipality was taken as focal point. Using both random and purposive sampling techniques, respondents were picked among councilors, top management and ordinary civil servants in Singida municipality.

The main findings of this study are that decentralization reform has not been effectively implemented in Sindiga municipality. The municipality did not have autonomy and powers in many areas that e decentralization was supposed to empower them. Political will, institutional framework, resource constrains are among factors that inhibit effective implementation of decentralization policy in Tanzania. Our main conclusion is that effective implementation of decentralization would demand a strong institutional framework and political will, all of which are the missing ingredients in the case of Singida municipality.
\end{abstract}

Keywords: Decentralization policy, Local governance and Local government Authorities in Tanzania.

\section{Introduction and Research Issues}

Decentralization, in its many forms has been a global public service reform. From developed world to the global south, many countries have implemented decentralization reforms. In describing the magnitude of the decentralization reforms, the World Bank (2011) observed that by 2000 , at least $95 \%$ of the democratic states in the world had elected local authorities and subsequently administrative, fiscal and political powers have been given to sub-national government at grassroots (Karlstrom, 2015; Makara, 2018). African countries were also not left behind in this reform trend. Since the 1990s, many African countries have tried to transfer resources and public service management to local government authorities (LGAs) such as counties, municipalities and cities (Dickovick \&Wunsch, 2014). Awortwi (2011) observed that by 2010 almost two-thirds (2/3) of countries in sub-Saharan Africa has executed some forms of decentralization reforms, purposely to bring the government closer to the people it seeks to serve. Likewise, World Bank (2011) as cited in Mbate (2017) suggests that, more than 50\% of African countries have devolved power, resources and functions from the centre to the grassroots. Some authors, have hence described the 1990s as an era dominated by devolution of authority, responsibilities and resources from central governments to grassroots authorities with the aim of enhancing local government authorities governed by locally elected bodies (Mbate, 2017; Obosi, 2019).

Ideally, decentralization reform is meant to create fundamental changes in how public services and resources are to be managed. In this sense, local authorities are expected to have more powers and mandates to manage public service delivery and resources at local communities' level. The aim of this policy move is to empower local communities so that they can have a say over not only the types and quality of public services they receive, but also they can easily know how public resources that are used to delivery their public services are being used. 
It should, however, be noted that powers attained by local authorities as a result of decentralization policy can be a source of conflict between central government and local government. It has remained an empirical question about how much power can be granted to local government in the decentralization reform and what can be the most appropriate balance of power between local governments and their superior central governments in the decentralization equilibrium. This is because, as much as decentralization is a political process, political actors, and especially those in the central government will always wish to retain some powers to oversee vast resources that should have to go to public service delivery in local governments in decentralization process. For instance, in Tanzania, local governments have often provided a ground over which politics of resources distribution is greatly played by political actors.

In general, decentralization reform raises several issues of research interest. In the first place, political actors in countries have different motives for undertaking decentralization reforms, although isomorphic factors and the desire to improve public service delivery seem to be driving factors. Isomorphic factors relate to countries imitating and implementing reforms that are being implemented elsewhere in the world. In this case decentralization may not be effectively implemented because of the missing internal driving factors. In addition, it should be noted that political and institutional factors are key determinants for effective implementation of decentralized reform. In this paper we seek to understand the extent to which decentralization reform has been effectively implemented in Tanzania and factors are likely to hinder its effective implementation. In the extant literature, empirical researches on these issues are inconclusive. Addressing these two research issues are critical if we are to properly deal with the question of the success and failure of the decentralization reforms in many parts of the world. The paper takes one of Tanzania's local authorities as its focal point. In the sections that follow we will provide a critical review of the current literature on decentralization reform and provide a methodological note. The subsequent sections will dwell on data analysis, discussion and conclusions.

\section{Decentralization Reform: An Overview}

The concept of decentralization has been defined in a variety of ways in the current literature. Houdret and Harnisch (2017) defines decentralization as the process of redefining and restructuring the structures, powers and governance practice in a country by devolving national power and responsibilities from the central government to the sub- national levels of government for the sake of bringing government closer to the people. For Obosi (2019) decentralization entails the process of devolving political, administrative and fiscal authority such as decision making and management of public services from national government to local authorities. Others defined decentralization as the transfer of authority and responsibility for public functions from the central government to subordinate or quasi-independent government organizations. The transfer of powers and autonomy can be through de-concentration, delegation, devolution or privatization/deregulation and it can involves (a combination of) dimensions of fiscal, administrative, political and economic powers and functions (Rondinelli, 1981, 1999; Steiner, 2005)

This paper defines decentralization as the process of transferring authority, responsibility and accountability of public service management from central government to local authorities. The paper also recognizes that decentralization may take several types including de-concentration, delegation and devolution. We further note that decentralization may be political, management/administrative as well fiscal in nature.

Administrative decentralization entails the process of transfering responsibility for the planning, financing and management of certain public functions from the central government and its agencies or to local government authorities. In this case, local governments are given specified powers to deal with issues of planning, managing and the delivery public services to the public in their respective localities. The most conspicuous form of administrative decentralization is devolution, a situation in which the central government transfers responsibilities for services to local governments that elect their political leaders (eg mayors and councils), raise their own revenues, and have independent authority to make investment decisions and human resources management (Egbenya, 2010). Theoretically, devolution is the most powerful form of decentralization because it is in this form of decentralization that local authorities get discretional powers over not only of public service management, but they have powers over human resources management and related fiscal issues in their jurisdiction. 
According to Egbenya (2010) fiscal decentralization is the situation in which decisions about expenditures of revenues raised locally or transferred from the central government are made by the local authority. In this case, local governments may have legal authority to impose and collect taxes, take loans from financial institutions, and spent collected revenue without the prior consent of central government. And finally, political decentralization is the transfer of political power to locally elected official to manage public service delivery at their local jurisdiction. This form is also called democratic decentralization, in which the central government transfers political power to local people to elect local politicians who will then take responsibility and accountability of managing public affairs including public services at their locality. It takes the shape of devolution and is the most far reaching type of decentralization as the local governments have the discretionary powers to make decisions and implement them within their jurisdiction (Steiner, 2005; Kauzya, 2007)

\section{The Rationale of Decentralization Reforms}

There are varied reasons why countries undertake decentralization reform. In some countries political reasons were the driving force of decentralization. For instance, in South Africa, Sri Lanka, Yugoslavia and Indonesia decentralization reforms were partly the reaction to ethnic, racial and regional conflicts that prevailed in their political system. Thus, decentralization was perceived as the solution to ever-ending conflicts in different countries in the world (Sutiyo, 2014; Martinez-Vazquez, et al, 2015). Similarly, in East Asia, and Central Europe, decentralization was considered as part of economic reforms geared towards transforming centralized public administration to decentralized government focusing on market economies (Cheema \& Rondinelli, 2007 as cited in Sutiyo, 2014; European Union, 2016). There are also strong political reasons of decentralization. It can be used as an instrument of domination, entrenching powers of the ruling elites at the grassroots level. It has been noted that, local authorities, which are theoretically meant to strengthen local democracy and to enhance popular participation, are today significantly used as patronage network to create and sustain electoral privilege of few elite at both national and local level (Jane \& Englebert, 2019) Evidence from of Kenya, Uganda, Zimbabwe, Nigeria, and Tanzania indicate that all these countries have used decentralized political system to consolidate the powers of the ruling party at both national and local level.

Theoretically, decentralization seems to be a more appealing form of local governance and its proponents assume that it will improve local governance and public service delivery in a number of ways. First, decentralization takes public service delivery close to the people and that enables those involved to have better understanding of local peoples' service needs and hence improves efficiency of resource allocation. Secondly, decentralization improves accountability through provision of information to local residents. This enables local people to have 'eyes on' bureaucrats who are delivering public services. Thirdly, decentralization can enhance the voice of citizens in decision making processes, and this in turn facilitate equitable distribution of services, especially to marginalized and poor communities. Effective decentralization therefore means that the local government is in touch with the citizens it seeks to serve. This argument is, effective local government is opposite to central government bureaucracies who are often seen as functionally distant, corrupt, hierarchical, rent-seeking organizations that are unaccountable, inefficient and ineffective at delivering public services. Decentralization is hence seen as panacea to problems associated with central government bureaucracies' bottleneck.

The presence of elected official in local governance can therefore easily put into spotlight rent-seeking behaviour of bureaucrats and this will subsequently enhance efficient and effective resources use and their associated accountability. Similarly, Stigler (1975 cited in Shah and Shah) makes two important points that warrants decentralization. Firstly, he says the closer a representative government to the people the better it works and secondly, the people should have the right to vote for the kind of public service they want.

For donors and international development agencies, decentralization reform can also service a different purpose. Firstly, decentralization can be a means of improving democratic system in a country. By shifting resources and authorities from central government to local government, the process is explicitly also empowering local people in making fundamental decision about the kind and the quality of service they prefer. Secondly, decentralization is sometimes seen as the most appropriate management system for poverty eradication. It is argued that decentralization allow local people to participation in decision- making 
process for issues that affects their livelihood. According to Egbenya (2010) there is a close correlation between decentralization and poverty reduction as the local people are empowered and given the resources and capacity to perform the function of developing their localities.

It is therefore clear that decentralization reforms are often undertaken to serve many varied aims. The main issue is how decentralization is implemented and whether or not policy objectives of decentralization reforms and are practically achieved.

\section{Implementing Decentralization Reform Effectively: The Issue of How}

Effective implementation of decentralization reform has been an issue of great interests for both researchers and practitioners. To realize its potential benefits, decentralization reforms must be effectively implemented. This means taking reform policy beyond its rhetoric by put it into action. However, implementing decentralization, like many other reforms has never been a smooth exercise, even for the most committed reform actors. As Smoke (2005) correctly puts 'Even with strong national commitment and careful design, implementation -the substance, timing, and sequencing of how new systems and processes are rolled out on the ground-is increasingly recognized as a key factor in whether positive outcomes can be realized and sustained.

The question of how decentralization should be effectively implemented is therefore both a theoretical and practical issue. Theoretically, effective implementation of decentralization would demand increasing fiscal, administrative and political autonomy to LGAs, something which is practically not easy to be achieved. It demands political will and capabilities both at central and local government level. The experiences and empirical evidence on the ground indicates that the reform often failed to achieve its stated theoretical objectives of empowering LGAs since the reforms is vulnerable to unwillingness of central government to devolve resources and power to local government at the grassroots (Smoke, 2015). Countries that have gone further in implementing decentralization reform have increased decision making autonomy to local government and grassroots institutions and this has improved public service delivery to the local populace (Mbate, 2017). We further agree with Fatile and Ejalonibu (2015) who opined that, the effectiveness of decentralization is accomplished through increasing fiscal, administrative and political autonomy to LGAs and providing people with quality and affordable public services provided by competent and non partisan public bureaucrats.

As noted earlier, effective implementation of decentralization is not a smooth exercise. A number of factors, both political and institutional can easily derail the implementation and process and that actual achievement of decentralization objectives. As Sutiyo (2014) has argued, strong political will and commitment from both political and bureaucratic leaders, clear legal and institutional framework, involvement of populace in governance process are vital for effective execution of the reforms. Therefore, having good design of decentralization cannot guarantee its effective implementation rather willingness of public officials and leaders from central government to disperse power, resources and functions to LGAs matters most (Cheema \& Rondinelli, 2007)

Additionally, local government themselves must have institutional capacity to absorb and executive decentralization policy. This implies that local governments must have institutional capacity in terms of organizational, human and financial resources that are required for decentralized government to effectively provide public services within their jurisdiction. Local governments needs to have autonomy, adequate resources both financial and competent human resources to put in place decentralization reform for effective and efficient delivery of public services. We will empirically examine the extent to which Tanzania's government has put in place these key ingredients of the decentralization reforms.

Effective decentralization may also demand clear legal framework for its execution. Olum (2014) asserted that, functioning constitutional and institutional mechanism is essential for successful execution of decentralization reforms. Enabling legal and institutional framework can create space for citizen's inputs and opinions in local governance. Proper institutional framework can also empower local people to oversee public officials (both politicians and civil servants) and this can curtail the rent-seeking habits of political leaders or technocrats for private gain. Therefore the provision political, fiscal and administrative power to LGAs would require legislation that would ensure the coordination of and the effective implementation of 
the reform. It is critical that local government derives their powers and mandate from clear a legal and legislated institutional framework than from the mere political will of the ruling elites.

\section{An Overview of Decentralization Reform Trajectory in Tanzania}

Since her independence from Great Britain in 1961, Tanzania has undertaken various decentralization reforms and for different reasons. Earlier decentralization strategy (from 1961 to mid 1971) was adopted to improve public services delivery at the grassroots (Kigume, Maluka \& Kamuzora, 2018). The national building agenda and the nationalization policy of the 1962 abolished traditional chiefdom system and colonial era native authorities in order to consolidate the powers of democratically elected local authorities (Kigume, et al, 2018). In this period, local authorities were established purposely to enhance the process of devolving power, resources and functions from central government to LGAs (Flumence, et al, 2013). Emerging from colonial ashes, the aim of the decentralization policy was to create institutional framework that would facilitate local level development and equitable public service delivery.

As part of decentralization reform, the government decided to scrap local government structures that were left by British colonial power. During British colonialism, local governments in Tanzania were organized around three structures, namely native authorities, districts and town councils, which were not really representative of local population, because these local authorities behavioured and acted like the agents of central government. Therefore in order to democratize development, in 1962, the Tanzania decided to carry out decentralization reform. The main aim was not only to scrap the British local government structures but also to strength local government and ensure local participation in local governance system. This decentralization reform policy re-established much stronger local authorities with more popular participation, meaning they were more representative of local population (Mollel and Tollenaar, 2013).

It should, however, be noted that, this was a period in which Tanzania was also drifting towards single party political system, in which the ruling Party - then Tanganyika African National Union (TANU) was becoming more and more powerful over the other state institutions. As a result, government system was inward looking with strong party leaders and eventually popular participation and meaningful decentralization was constrained. In additional, local governments of the time did not have enough and skilled personnel, the situation that forced central government to retail the traditional role of public service delivery.

Again, decentralization reform in Tanzania faced another setback between 1967 and 1972. In 1967, Tanzania adopted a landmark development policy popularly known as Arusha Declaration, a policy ideology, which completed changed Tanzania to a Socialist country under the umbrella of Ujamaa ${ }^{1}$ ideology. Under Ujamaa ideology, not only all state powers were centralized but also all major means of production were nationalized. The ruling Party (TANU) became the supreme organ of state, assuming all state and government powers. As Mollel and Tollennar 2013) noted, the result was an even stronger central government in the management of local authorities. By 1972 the government abolished local government authorities, the argument being that local people's participation in decision -making can be achieved through the ruling party structures. In this regards, instead of using local government structures local people can use ruling party branches in their locality to express their views.

Therefore the 1972 Act, legalized de-concentration system of decentralization as well as the abolition of local government authorities, but empowered Regional Development Committees (RDC), District Development Councils (DDC) and Ward Development Committees (WDC). This move handed back to the central government all responsibilities and functions that were performed by LGAs (Likwelile \& Assey, 2018). According to Mollel and Tollennar (2013) this ruling Party-based decentralization approach was expected to enhance popular participation and to make bureaucracy more accountable to the ruling party (then TANU).

Another round of decentralization reform started in 1982, where the government restated local government authorities for the aim of enhancing local people's participation in local development. To ensure smooth functioning of local authorities, the ministry of local government was established. The amendment of the Constitution of the United Republic of Tanzania of 1977 through Act No. 15 of 1984 was meant to give

${ }^{1}$ Ujamaa is Swahili name that can be equated to Socialism in English 
local authorities more powers in the running of local affairs. However, despite this constitutional amendment, central government still yielded a lot powers over local government. The central government controlled social-economic and political agenda of LGAs at the grassroots level and people's expectations were not really achieved (Mnyasenga \& Mushi, 2015; Kigume et al, 2018).

By the 1990s, it was clear that earlier efforts on decentralization were not working in Tanzania. In fact, this period witnessed a wide range of reforms being undertaken in Tanzania and local government reform was a component of these wide ranging reforms. For example, politically, the Tanzania decided to embrace multiparty politics, the move that widened political and democratic space to Tanzanians. The Government also abandoned socialism ideology in favor of liberalism and because of this turn, Tanzania implemented some far reaching neo-liberal social-economic policies under the tutelage of donors, especially the World Bank and IMF.

It was within this context that a comprehensive Local Government Reform Programme (LGRP) was launched in 1996. The aim of the new reform was to create autonomous, strong and effective local authorities that derives their legitimacy from improved service delivery ( Mollel and Tolennar 2013). It also seeks to foster participatory approach to development that reflects local demands and conditions. In addition, the new decentralization approach seeks to empower local people in decision making about their development and also to ensure they participate in local governance through their representatives. This is expected to improve transparency and accountability of public officials to the electorates

To give it more emphasis and importance, the new decentralization policy was named Decentralization by Devolution, popularly known as D by D in the Tanzania's literature. Theoretically, D by D was supposed to be a powerful form of decentralization than those previously attempted in Tanzania. Its objective was to transfer mandates, responsibility, financial resources and human resources management from central government to local government authorities. In turn, local governments were mandated to improve public service delivery. In fact, following the adoption of $\mathrm{D}$ by $\mathrm{D}$, the management of most basic public service like health, education, water and land management were transferred from central government to local authorities. Local governments were supposed to raise some revenues to finance these public services, but much of the funding would still come from central government. In this research we will partly examine the extent to which D by D reform has been successfully implemented.

\section{Methodological Notes}

This research is based on a case study design. The study used Sindiga municipal council - a decentralized local authority as its focal point. Administratively, the council is headed by Municipal director, an appointee of ${ }^{2}$ central government. The municipal director is assisted by heads of sections/units who are also theoretically the appointees of central government ${ }^{3}$. Following decentralization, elected councilors forms the municipal council. This study collected data from both civil servants and political leaders in Singida Municipality.

Both primary and secondary data are used in this research. For primary data, interviews and questionnaire were used for data collection. For secondary data, the study relied on documentary review. Using both probability and non-probability sampling techniques, data were collection from the following categories of staff; Municipal Director, sixteen (16) Heads of Departments and Units, twenty six (26) Councilors and one hundred and five (105) lower cadre employees. Content analysis and social science statistic analysis software were used as methods of data analysis.

\section{Research Findings and Discussions}

\subsection{The Implementation of Decentralization Reform in Tanzania: Empirical Evidence}

The first question this paper seeks to address is -to what extent decentralization reform has been implemented in the area of our case study. It has been argued that for a reform to yield its expected results it must be effectively implemented and therefore analysis of to what extent a reform has been put into practice is a key empirical issue. In order to address this important research question we use two-staged approach.

\footnotetext{
2 In Tanzania, City and Municipal Directors are appointed by the President of the country

${ }^{3}$ Heads of Departments, although purely they are civil servants, they are appointment by the minister of local Government
} 
First, we examined the process used to implement decentralization reform in Singida municipality. Our understanding is that effective implementation of a reform is dependent on the proper processes and procedures used to implement a reform. This includes whether or not actors know the implementation process and other guiding policies for decentralization reform. Therefore issues that guided our empirical focus were as follows: Whether respondents have idea about decentralization policy and its implementation process, whether laws and policies facilitated the process of implementing decentralization reforms; whether the creation of decentralized institutions facilitated the implementation process of the reforms and the extent to which public employees are satisfied with the organizational set up between central and local governments in the process of implementing decentralization reforms.

Table 1: The Process of Implementation of Decentralization Reforms in Tanzania (N.37).

\begin{tabular}{|c|c|c|c|}
\hline Statements or Questions & $\begin{array}{l}\text { Response } \\
\text { statements }\end{array}$ & Frequency (n) & Percentage \\
\hline $\begin{array}{l}\text { Do you have any idea about decentralization } \\
\text { reform and its process? }\end{array}$ & $\begin{array}{l}\text { Yes } \\
\text { No }\end{array}$ & $\begin{array}{l}31 \\
6\end{array}$ & $\begin{array}{l}83.8 \\
16.2\end{array}$ \\
\hline $\begin{array}{l}\text { Do you know any laws or policies which were } \\
\text { used as a guideline in the process of } \\
\text { implementation of decentralization reform? }\end{array}$ & $\begin{array}{l}\text { Yes } \\
\text { No } \\
\text { I don't know }\end{array}$ & $\begin{array}{l}22 \\
9 \\
6\end{array}$ & $\begin{array}{l}59.5 \\
24.3 \\
16.2 \\
\end{array}$ \\
\hline $\begin{array}{l}\text { Do you think the existing laws and policies } \\
\text { facilitated the process of decentralization } \\
\text { implementation in your council? }\end{array}$ & $\begin{array}{l}\text { Yes } \\
\text { No }\end{array}$ & $\begin{array}{l}14 \\
23 \\
\end{array}$ & $\begin{array}{l}37.8 \\
62.2 \\
\end{array}$ \\
\hline $\begin{array}{l}\text { To what extent laws and policies of } \\
\text { decentralization enabled the process of } \\
\text { implementation of decentralization reforms in } \\
\text { Singida Municipality. }\end{array}$ & $\begin{array}{l}\text { Great extent } \\
\text { Moderate extent } \\
\text { Limited extent } \\
\text { Very limited extent } \\
\text { Non responses }\end{array}$ & $\begin{array}{l}4 \\
11 \\
16 \\
3 \\
3\end{array}$ & $\begin{array}{l}10.8 \\
29.7 \\
43.2 \\
8.1 \\
8.1 \\
\end{array}$ \\
\hline $\begin{array}{l}\text { To what extent the creation of decentralized } \\
\text { institutions facilitated the process of } \\
\text { implementation of decentralization reforms in } \\
\text { Singida Municipality? }\end{array}$ & $\begin{array}{l}\text { Great extent } \\
\text { Moderate extent } \\
\text { Limited extent } \\
\text { Very limited extent }\end{array}$ & $\begin{array}{l}4 \\
8 \\
24 \\
1\end{array}$ & $\begin{array}{l}10.8 \\
21.6 \\
64.9 \\
2.7 \\
\end{array}$ \\
\hline $\begin{array}{l}\text { Are you satisfied with the organizational } \\
\text { arrangement between central and local } \\
\text { governments in the process of implementation } \\
\text { of decentralization reform? }\end{array}$ & $\begin{array}{l}\text { Yes } \\
\text { No }\end{array}$ & $\begin{array}{l}16 \\
21\end{array}$ & $\begin{array}{l}43.2 \\
56.8\end{array}$ \\
\hline
\end{tabular}

\section{Source: Research Findings, 2019}

As shown in Table 1 above, it seems like most actors (83\%) understand, not only decentralization reforms in Tanzania, but also the guiding policies and laws upon (59\%) which decentralization reform is based. But it looks ironic, that the same actors do not believe that the guiding policies and laws can facilitate effective implementation of decentralization reform. Table 1 above shows that most respondents (62.2\%) do not believe that the existing decentralization policies and laws can facilitate effective implementation of decentralization reform and $64 \%$ of them see the institutional arrangement for decentralization reform as problematic. The reason why most respondents negatively perceived decentralization policy and its subsequent institutional arrangement for decentralization is beyond the scope of the current research. For instance, some respondents said that decentralization policy failed to create demarcation of powers and to 
define clearly power of each tire of the government hence local authorities are merely seen as the agents of central government.

Our documentary review has confirmed the skepticism of our respondents in Singida municipality. For instance, while local authorities have some power to make by-laws in their respective jurisdiction, the bylaws they make are subject to ministerial approval as indicated in section 54(1) and 80(1) of the Act No.7 \& 8 of 1982. Again, according to section 6(1) (a)-(u) of the Local Government Finance Act No.9 of 1982 as amended in 2006, local authorities can set tax rate, find sources of revenue, collect own revenue, spend the collected revenue according to local priorities, but in recent years (since 2015) most of their revenue base/sources have been taken back by central government. More over, the President of Tanzania has recently directed Local government authorities not to take loans at all from any financial entity without the approval of central government. This means that local governments do not have any autonomy over local government finances. During the interview, one respondent was clearer on local government's weak autonomy over finances;

"The recent re-centralization of most reliable sources of revenue which are enormous and effortless to collect such property tax, billboard tax, parking fee has left local councils with revenue sources which are difficult to collected and this has serious affected the financial autonomy of LGAs. (Interview, 3, April, 2019)".

Another important feature of a decentralized local government system could have been their autonomy over human resources management in their jurisdiction. Theoretically and especially in the context of D by $\mathrm{D}$ in Tanzania, the role and mandates of Local Government Authorities over their human resources are provided in a number of legislations. These include Local Government Finance Act, 1982; Public Services Act No.8 of 2002 as amended in 2007and its regulation of 2003 respectively. These legislations and many others attempted to demarcate the boundaries and role of local government and those of central government over human resources. Local authorities were supposed to have mandates and powers for the recruitment, promotion, training, and disciplining employees within local authorities

Our empirical evidence, however, suggests that LGA authorities have very limited powers of HRM in their jurisdiction. In fact, recruitment and selection procedures in LGA are dominated by central government and especially for top and managerial level positions. The central government appoints cities, municipals and district council directors. This mandate is given to the President and minister for local government for obvious reasons. These top local government positions are politicized and political elites must ensure that the office hold of these positions know how to play politics. These top LGA officials play a very crucial role during the local governments and general election. Apart from overseeing elections in their areas, they are also the returning officers of elections and they directly report to the National Electoral Commission.

Cities and Municipal directors are assisted by heads of departments. Common departments in Tanzania's local government authorities are education and culture, trade and economic affairs, health and social welfare, planning and finance, and personnel and administration. Throughout the country, the heads of these departments are appointed by the minister for local government ( Kinemo et al. 2015). The powers of local government authorities are also constrained even for low level employees. Their recruitment is done by a central government recruitment agency called Public Service Recruitment Secretariat (PSRS). For specialized sectors like health and education, the ministry of education and health determines recruitment process and final appointment of employees in this cadre.

Furthermore, local government authorities don't have any say over pay and other remunerations of their employees. As Kinemo et al. (2015) have correctly noted 'local authorities have no say in the design of pay systems (salary scales, salary levels, and retirement benefits schemes) for their employees'. According to the Public Service Pay and Incentive Policy of 2010, it is the role of central government to develop pay and reward system in the entire public service (which includes local governments). In fact, the Ministry of Finance and President's Office, Civil Service Management are responsible for wage management in the entire public service in Tanzania. 
Our field interviews also revealed the power of central government over civil service in local authorities. In this regard, one of our respondent has this to say about the powers of local government over civil servants in their jurisdiction;

"Regardless of the goodwill of the government, the re-centralization of recruitment system in 2009 under PSRS following the amendment of Public Service Act, No 8 of 2002 and Section, No 29 of the Act No.18 of 2007, grabbed administrative power of the council in terms of determining the requirements, number of establishments, recruitments and appointments of higher rank positions hence stated to experience delays in filling vacant posts and resulting to the shortage of staff in the council.(Interview, 22,March,2019)".

We want to conclude our analysis in this section by a quote from one of our respondent during the field research who said following regarding decentralization in Tanzania;

"Decentralization by Devolution is not effectively implemented in local government authorities by central government since LGAs have little autonomy and discretionary authority over governance process, human and financial resources and worse enough relies on financial resources from government transfer for over $95 \%$.(Interview, 18,March,2019)".

From the foregoing analysis it is clear that central government has still retained its traditional powers over local government authorities in Tanzania. In the next section, we shall attempt address the question of why decentralization policy has been poorly implemented in Tanzania? In other words, we seek to analyze factors that hinder effective implementation of centralization reforms in Tanzania.

\section{The Challenges of the implementation of Decentralization Reform in Tanzania}

The second objective of this paper is to examine the challenges facing decentralization reform in the Tanzania's local government. Of course, challenges facing decentralization reforms are many, not only in Tanzania, but these challenges are global in nature. As illustrated by our findings in Table 2 below, the most conspicuous challenge is the 'political will to decentralize'. Most of our respondents (48\%) are of the opinion that politicians are not willing and committed to see decentralization policy effectively implemented. Additionally, most respondents (72\%) also believe that decentralization reform in Tanzania is placed in a weak legal and institutional framework. Our documentary review also confirmed that decentralization reform is facing serious weak legal and institutional framework. For example, the minister responsible for local government enjoys vast powers over LGAs as stipulated in Local Government Act No.7, 8\&9 of 1982 and its amendments. All these legislations grants enormous power to the minister to supervise and control tasks, functions, and resources of LGAs through its regulations, directives and some direct interventions over issues are deemed of local governments.

Table 2: Factors Impeding the Implementation of Decentralization Reform in Tanzania's LGAs (N.37)

\begin{tabular}{|l|l|l|l|}
\hline \hline Studied Variables & Response statements & Frequency (n) & Percentage \\
\hline $\begin{array}{l}\text { The process of devolving resources and } \\
\text { functions to local authorities so far is } \\
\text { smooth, efficient and effective }\end{array}$ & Strongly disagree & 11 & 29.7 \\
& $\begin{array}{l}\text { Disagree } \\
\text { Neutral, }\end{array}$ & 15 & 40.5 \\
& Agree & 2 & 18.9 \\
The central government is willing and \\
$\begin{array}{l}\text { committed to ensure the decentralization } \\
\text { process is effectively implemented. }\end{array}$ & Strongly disagree & 9 & 5.4 \\
& Disagree & 17 & 5.4 \\
\hline There is an adequate financial resource for & Strongly disagree & 4 & 24.3 \\
\hline
\end{tabular}




\begin{tabular}{|l|l|l|l|}
\hline \hline Studied Variables & Response statements & Frequency (n) & Percentage \\
\hline $\begin{array}{l}\text { public services delivery which matches } \\
\text { with the degree of decentralized functions. }\end{array}$ & $\begin{array}{l}\text { Disagree } \\
\text { Neutral, } \\
\text { Agree }\end{array}$ & 25 & 67.5 \\
& Strongly agree & 8 & 8.7 \\
\hline $\begin{array}{l}\text { There is weak legal framework that } \\
\text { defines clearly the functions of each level } \\
\text { of government and to ensure local } \\
\text { government autonomy }\end{array}$ & $\begin{array}{l}\text { Strongly disagree } \\
\text { Disagree }\end{array}$ & 3 & 21.6 \\
\hline $\begin{array}{l}\text { Politicians are not willing and committed } \\
\text { to engage in effective implementation of } \\
\text { the reform }\end{array}$ & Strongly disagree & 5 & 8.1 \\
\hline & Disagree & 2 & 13.5 \\
& Strongly agree & 4 & 5.4 \\
\hline \hline
\end{tabular}

\section{Source: Research Findings, 2019.}

It is hence clear that the implementation of decentralization reforms were impeded by lack of political commitment and willingness from government officials, limited local government autonomy over local affairs and weak legal framework which fails to define clearly, powers and responsibilities of each tier of government. Arguably, lack of knowledge and awareness among councilors and the entire community on decentralization reform and hostile relationship and overlapping roles and powers between the central and local governments impede the effectiveness of decentralization reforms in LGAs in Tanzania

\section{Discussions and concluding remarks}

This paper addressed two important questions about decentralization reform in Tanzania. It first, focused on the decentralization process and the extent to which decentralization policy was effectively implemented. The main observation of this paper is that decentralization reform has only been implemented to a limited extent. Just like elsewhere in most African countries, central government has retained most powers over local governments. Our findings are not so much dissimilar to most research on decentralization in Africa. For instance, Gaynor (2018) noted that devolution of powers and resources to LGAs in Tanzania are curtailed by resistance and unwillingness of central government leaders who exert their control over local government's affairs through a number measures such as revising council's budgets before approval. Again, as noted in this paper, decentralization pronouncement goes hand in hand with the creation of institutional framework that constrained its effective implementation. For example, while the government was developing decentralization policy, it did not revise the Public Service Act No.8 of 2002 as amended by Act No.18 of 2007, Public Service Regulations 2003, and Public Service Scheme, 2003 all of which control civil service in the country, including those in local government authorities.

As such some authors have even questioned the relevance of decentralization reform in Africa, arguing that its full implementation is unrealistic (Mollel and Tollenaar, 2013, Smoke 2015). That sense of unrealistic 
devolution could come from that the fact that politicians have different motivations in adopting decentralization reform and it is that hidden motivations which eventually determine the actual implementation the reform.

As noted in this research paper, decentralization reform in Tanzania has been placed in weak institutional framework and as such local government authorities operate in a loose legal foundation over anything they do. As such they operate like the agency of central government. This observation is not limited to Tanzania; other developing countries like Uganda, Zimbabwe show a similar gap between decentralization policy and its actual implementation. Perhaps it is fair to say that decentralization is a political phenomenon pursued when it fits the political interest of those in power and hence it is naïve to assume that its pronouncement will be followed by its effective implementation. However, despite the fact that decentralization reform is facing implementation challenges, it will remain a significant reform trend for the foreseeable future and there is no indication that the central government will usurp the limited powers of local authorities or abandoned decentralization policy in Tanzania

\section{Acknowledgements}

The initial part of the data collection for this paper was undertaken by Martin Fute, a former post graduate student at Mzumbe University. The author acknowledges his contribution in data collection but is solely responsible for the context and analysis of this paper.

\section{References}

[1.] Anosisye, M.K (2017). Decentralization by Devolution: Perception of Councilors on Their Exercise of Fiscal Decision-making Authority in Local Government Authorities in Tanzania, Journal of Political Sciences \& Public Affairs, 5(2),1-5.

[2.] Awortwi, N (2011). An unbreakable path? A comparative study of decentralization and local government development trajectories in Ghana and Uganda, International Review of Administrative Sciences, 77(2), 347-377.

[3.] Bannink, D \& Ossewaarde, R (2012). Decentralization New Modes of Governance and Administrative Responsibility, Administration \& Society, 44(5), 595- 624.

[4.] Beshara,C, Downing,C, Holbreich,M \& Singh, P (2014). Decentralization in Unitary States: Constitutional Frameworks for the Middle East and North Africa. Project Paper. International IDEA.

[5.] Cabral,L (2011).Decentralization in Africa: Scope, Motivations and Impact on Service Delivery and Poverty, Working Paper 020.

[6.] Dickovick,J.T(2014). Foreign Aid and Decentralization: Limitations on Impact in Autonomy and Responsiveness, Public administration and development. 34, 194-206.

[7.] Erdal. A (2018). Measurement of Public Sector Decentralization under the Light of Global Trends, Indian Journal of Research, 7 (10). 74-76.

[8.] Fatile, J.O \& Ejalonibu, G.L (2015). Decentralization and Local Government Autonomy: Quest for Quality Service Delivery in Nigeria, British Journal of Economics, Management \& Trade, 10(2): $1-21$.

[9.] Fissha, S (2017). Decentralization as Commitment to Rise Public Services and Improve Quality of Rural Life in Ethiopia, A Case Study, Journal of Public Administration and Governance, 7(4), 255277.

[10.] Fitriah, A (2017). Decentralization, Identity Construction, and Conflict: Education under Aceh's Special Autonomy, PhD Thesis, Massey University, Palmerston North, New Zealand.

[11.] Fjeldstad, O. H., \& Katera, L. (2017). Theory and Practice of Decentralization by Devolution: Lessons from a Research Programme in Tanzania (2002-13).REPOA.

[12.] Fjeldstad,O.H, Ali,M \& Katera, L(2017). Policy implementation under stress: Central-local government relations in property tax collection in Tanzania, CMI Working Paper. No.1.

[13.] Flumence, G, Nyamhanga. T, Mwangu, M \& Hurtig. A (2013). Challenges to the implementation of health sector Decentralization in Tanzania: experiences from Kongwa district council. International Inter-university Global Health Partnerships Project, 6.1-11. 
[14.] Egbenya, G. (2010) The effectiveness of decentralization policy in Ghana: A case study of Komenda-Edina-Eguafo-Abrim (KEEA) and Abura -Asebu- Kwamankese (AAK) districts in Ghana: African Journal of Political Science and International Relations Vol. 4(1), pp. 013-028

[15.] Gaynor, N (2018). Challenges to Decentralization in the Democratic Republic of the Congo: Beyond the Political Settlement, Journal of International Development, (2018), 1-17.

[16.] Houdret,A. \& Harnisch,A.(2017). Decentralization in Morocco: The Current Reform and Its Possible Contribution to Political Liberalization, Discussion Paper, 11/2017, GDI.

[17.] Jagero. N, Kwandayi.H.H \& Longwe.A (2014). Challenges of Decentralization in Malawi, International Journal of Management Sciences, 2(7), 315-322.

[18.] Jesse,A \& Bengesi, K.M.K (2018). Resource Complementarity for Social Service Delivery: A Case of Corporates and Local Government Authorities in Morogoro, Tanzania, Journal of Management and Sustainability; 8(3), 25-35.

[19.] Kalufya,N, Michael, F \& Chalu, H (2018). Human Resource Management Reforms and Public Sector Governance in Tanzania: An Application of Decentralization Perspective, ORSEA Journal, 8 (1), 50-67.

[20.] Karlström, K (2015). Decentralization, Corruption and the Role of Democracy, Working Paper Series 2015:4.

[21.] Karmel, E (2017). Decentralizing Government. What do you need to know? Democracy Reporting International, Briefing Paper, No.87.

[22.] Kessy, A (2013). Decentralization and Citizen's participation; Some Theoretical and Conceptual Perspective, African Review, 40(2), 215-239.

[23.] Kessy, A.T (2018). Decentralization, Local governance and Path Dependency Theory, Utafiti, 13(1), $54-76$.

[24.] Kessy,A \& Mushi,R (2018). Institutional and Legal Analysis of D-by-D in Tanzania: Rhetoric vs Reality, REPOA

[25.] Kigume,R \& Maluka,S (2018).Decentralization and Health Services Delivery in Four Districts in Tanzania: How and Why Does the Use of Decision Space Vary Across Districts? International Journal of Health Policy Management, 10(10), 1-11.

[26.] Kigume R \& Maluka S. (2019). Decentralization and health services delivery in 4 districts in Tanzania: how and why does the use of decision space vary across districts? International Journal of Health Policy Management, 8(2):90-100.

[27.] Kimengsi,J.N \& Gwan, S.A (2017). Reflection on Decentralization, Community Empowerment and Sustainable Development in Cameroon, International Journal of Emerging Trends in Social Sciences, 1(2), 53-60

[28.] Kim,S,Smith,W, Sommers,M \& Varela, M(2015). Power to the people; A comprehensive Analysis of Decentralization in the East African Community.

[29.] Kinemo, et al.. (2015). Decentralization of Human Resources Management in Tanzanian Govermental organizations, in RIDDER, K. et all (2015) Public Administration in Tanzania; Current issues and Challenges, African Studies Centre, Leiden

[30.] Likwelile,S \& Assey, P. (2018). Decentralization and development in Tanzania, Tanzania Institution Diagnostic.

[31.] Makara,S. (2018). Decentralization and good governance in Africa: A critical review; African Journal of Political Science and International Relations, 12(2), 22-32.

[32.] Malinga,W, Moyo, P.M.Z.S, Sokhosana, N \& Moyo,M (2017). Decentralization and Rural Development: Is it a Policy of Empowering or Disempowering Rural Communities in Zimbabwe? International Journal of Innovative Research \& Development, 6(4), 132-143.

[33.] Martinez-Vazquez,J, Lago-Peñas,S \& Sacchi,A(2015).The Impact of Fiscal Decentralization: A Survey, International Center for Public Policy Working Paper 15-02.

[34.] Mollel, H and Tollenaar, A . (2013) Decentralization in Tanzania: Design and Application in Planning Decisions; International Journal of Public Administration: 36: 344-353

[35.] Mooketsane, K, Bodilenyane.K \& Motshekgwa.B (2017). Is decentralization in Botswana a democratic fallacy? African Journal of Public Affairs, 9 (5), 47-60. 
[36.] Mutahaba,G \& Parestico, P. (2015). Local Government Capacities in East Africa, Public Policy and Administration, 14(3), 268-280.

[37.] Mbate, M. (2017). Decentralization, Governance and Accountability: Theory and Evidence, Journal of African Democracy and Development, 1(2). 1-16.

[38.] Mmari, D \& Katera, L (2018). Limits to citizen engagement and downward accountability in the context of decentralization by devolution in Tanzania. REPOA.

[39.] Mpambije, C.J (2016).Decentralization of Health Service Provision in Tanzania: Are Local Government Authorities Improving Anyway? Evidence from Local Government Authorities Audit Reports; International Journal of Social Science and Humanities Research, 4 (3). 461-472.

[40.] Obosi, J. O. (2019).Decentralized Governance in the Management of Urban Health Care Systems in Developing Countries, Open Journal of Political Science, 9, 189-202.

[41.] Ochieng, K.O (2017).Who is responsible? Local government and accountability for service delivery in Kenya's devolved health sector, Commonwealth Journal of Local Governance, 20 , $1-14$.

[42.] Olum,Y (2014). Decentralization in developing countries: Preconditions for successful implementation, Commonwealth Journal of Local Governance, 15, 23-38.

[43.] Ozmen, A (2014). Notes to the Concept of Decentralization, European Scientific Journal, 10(10), 415-424.

[44.] Ridder, K.D, Emans,B, Hulst,R \& Tollenaar,A (edts)(2015). Public administration in Tanzania,current issues and challenges, African Studies Centre.

[45.] Saunders, C (2018).Constitutional Design: Options for Decentralizing Power, Constitution Transformation Network, Policy Paper No. 2.

[46.] Sutcliffe, M (2014). Local Democracy Today and Tomorrow-Learning from Good Practice, A background paper for a workshop on local democracy held at International IDEA offices in Stockholm, November 2014.

[47.] Sutiyo, B. (2014). Decentralization: Potentiality and Challenge for Rural Development, Journal of International Development and Cooperation, 20(3). 5-12.

[48.] Shaningwa, L.M (2012). The Effectiveness of Decentralization Policy on Service Delivery in the Education Sector: Master Thesis, The University of Namibia, Namibia.

[49.] Slavova,M \& Okwechime,E (2016). African Smart Cities Strategies for Agenda 2063, Africa Journal of Management, 2 (2), 210-229.

[50.] Smoke, P (2015). Managing Public Sector Decentralization in Developing Countries: Moving Beyond Conventional Recipes, Journal of Public Administration and Development, 35, 250-262.

[51.] Wagana. D, M, Iravo,M.A \& Nzulwa. J, D (2015).Analysis of the Relationship between Devolved Governance, Political Decentralization and Service Delivery: A Critical Review of Literature, European Scientific Journal, 11(31), 457-472. 